\title{
Food and nutrient intake of a national sample of 4 -year-old children in 1950: comparison with the 1990s
}

\author{
CJ Prynne ${ }^{1, *}$, AA Paul ${ }^{1}$, GM Price ${ }^{1,2}$, KC Day $^{1}$, WS Hilder ${ }^{3}$ and MEJ Wadsworth ${ }^{3}$ \\ ${ }^{1}$ MRC Human Nutrition Research, Downham's Lane, Milton Road, Cambridge CB4 1XJ, UK: ${ }^{2}$ Present address: \\ MRC Institute for Environment and Health, University of Leicester, 94 Regent Road, Leicester LE 1 7DD, UK: \\ ${ }^{3}$ MRC National Survey of Health and Development, University College and Royal Free Medical School, \\ 1-19 Torrington Place, London WC1E 6BT, UK
}

Submitted 10 March 1999: Accepted 16 June 1999

\begin{abstract}
Objective: To evaluate the food and nutrient intake of members of a birth cohort study when young children in 1950 and investigate differences from present-day children's diets.

Design: One-day recall diet records from the MRC National Survey of Health and Development (NSHD) (1946 Birth Cohort) at age 4 years were analysed for energy and selected nutrients and compared to the published results for 4-year-olds in the 1992/93 National Diet and Nutrition Survey (NDNS).

Setting: England, Scotland and Wales in 1950 and 1992/93.

Subjects: 4599 children in 1950 and 493 children in 1992/93.

Results: Mean (SD) daily intakes in 1950 were energy 1445 (343) kcal, or 6.1 (1.4) MJ, protein 46 (11) g, fat 64 (20) g, starch 117 (33) g, sugar 62 (24) g, unavailable carbohydrate 13 (4) g, calcium 736 (230) $\mathrm{mg}$, iron 7.7 (2.1) $\mathrm{mg}$, retinol 738 (1273) $\mu \mathrm{g}$, carotene 1049 (1130) $\mu \mathrm{g}$ and vitamin C 40 (26) mg. Compared to 1992/93, the 1950 diet contained substantially more bread and vegetables and less sugar and soft drinks, giving it a higher starch and fibre content and making it more in line with current recommendations on healthy eating. However, fat provided 40\% of energy in 1950 , compared to 35\% in 1992/93. In 1950, red meat was an important source of iron, but by 1992 most iron came from fortified breakfast cereals. Vitamin C came mainly from vegetables in 1950, but from soft drinks in 1992.

Conclusions: The relative austerity of post-war food supplies resulted in food and nutrient intakes in 1950 which in many respects may well have been beneficial to the health of young children, despite fat intake being higher than present-day recommendations.
\end{abstract}

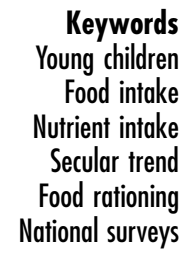

Keywords Young children

Secular trend Food rationing National surveys
Diet in childhood is of paramount importance to the well-being and growth of the child, and it is also of great interest as a potential influence on adult morbidity and mortality. Epidemiological studies have demonstrated that birthweight and infant weight at 1 year, which can be regarded as indicators of early nutrition, are strongly related to cardiovascular disease and associated risk factors in adulthood ${ }^{1}$. Diet in preand early postnatal life of premature infants has a clear affect on health and cognitive outcomes in childhood ${ }^{2}$, and the initial feeding of full-term infants also shows some relation to later cognitive development ${ }^{3}$. But it is more debatable whether diet in childhood is also important in similar ways to subsequent health and development ${ }^{4}$.

Children born in 1946 lived through a time of postwar austerity in their early years, but in adulthood are more prosperous ${ }^{5}$, this combination possibly making them particularly vulnerable to degenerative diseases in later life ${ }^{6}$. On the other hand the war-time diet, with its greater reliance on bread and vegetables and lower amount of fat and sugar compared to present times was closer to present-day recommendations for a healthier diet. A number of foods were still in short supply or rationed into the $1950 \mathrm{~s}^{7}$, so the diet at this time would have retained war-time features. There are positive and negative factors therefore which may have been influencing both childhood and adult health. Although there is comprehensive data available on household food supplies and nutrient intake in $1950^{8}$, there is little information on the food and nutrient intake of young children at that time. Investigations of the role of early diet in later disease outcome have therefore been limited by the lack of dietary knowledge.

The present study aims to redress this limitation, and is a component of a major longitudinal investigation of lifetime influences on health and development ${ }^{5,9}$. As part of increasing the understanding of relations 
between diet and health, the present paper examines the extent to which the diet of young children in 1950 differed from that of the present time. Food and nutrient intake at the age of 4 years are described, in the context of post-war austerity and food rationing, using 24-hour dietary recalls which were collected at interview in 1950, but had not been processed or analysed before the present study. Results published from the recent National Diet and Nutrition Survey (NDNS) of preschool children ${ }^{10}$ were used in the comparison across 40 years. Macronutrients and those micronutrients for which there is particular health interest, and data for foods in 1950 were considered to be sufficiently reliable, are covered in the analysis.

\section{Methods}

\section{Subjects and data collection}

The subjects were 4700 children living in England, Wales and Scotland who were 4 years old in 1950. They represented $88 \%$ of the 5362 children selected for the MRC National Survey of Health and Development (NSHD) (1946 Birth Cohort) as a class-stratified random sample of the 12930 legitimate, singleton babies who were born in the week of 3-9 March 1946. Those that had died, emigrated, were living abroad or could not be traced comprised the remaining $12 \%$.

A wide range of information about health, lifestyle and social background was collected by local health visitors at a home visit ${ }^{11}$. The majority of these visits were in June (73\%) and July (19\%) 1950, and most of the rest took place during the 1950/51 winter. Visits were spread through the week in approximately equal proportions from Monday to Friday (between 17\% and $21 \%$ of the total), but only $3 \%$ were on a Saturday and less than $1 \%$ on a Sunday. Of the 4700 children whose carer was interviewed, useable dietary information was obtained from 4599 (98\%), comprising 2404 boys and 2195 girls. No dietary records had been obtained from those children in hospital (5), ill at home (4), staying with relations (7), in residential nurseries (3) or for unstated reasons (82). Social class ${ }^{12}$ distribution of the fathers of these 4599 children was SC I 5.6\%, SC II $15.8 \%$, SC IIINM $17.5 \%$, SC IIIM 30.4\%, SC IV $20.3 \%$, SC $\mathrm{V}$ 6.3\%, and unclassified (including armed services) $3.9 \%$. Mean (SD) heights and weights measured on over $92 \%$ of the study population were for boys and girls respectively, $103.4(5.3) \mathrm{cm}(n=2235), 102.6(5.3) \mathrm{cm}$ $(n=2021), 17.6(2.2) \mathrm{kg}(n=2302)$ and $17.0(2.3) \mathrm{kg}(n=$ 2096). Basal metabolic rate (BMR) was calculated from body weight, using the equations ${ }^{13}$ : boys BMR (kcal day $\left.^{-1}\right)=22.7 *$ wt $(\mathrm{kg})+495$; girls BMR $\left(\mathrm{kcalday}^{-1}\right)=$ $22.5 * \mathrm{wt}(\mathrm{kg})+499$. In order to provide some validation of energy intake, the parameter energy intake: basal metabolic rate (EI : BMR) was calculated.

\section{Dietary records}

Descriptive information about diet had been obtained by asking the mother or carer 'What did this child have for each meal yesterday?' and referring specifically to 'Breakfast', 'Dinner', 'Tea or high tea' and 'Last thing at night'. There were, however, few indications of amounts of food. For the present study, NSHD staff prepared a text data file from the archived dietary records. A further question was 'Do you give this child food between meals?' It had a 'Yes', 'No' or 'No answer' response, but no further information.

\section{Coding and nutrient analysis}

The diet records were coded using the in-house program, DIDO (Diet In Data Out) ${ }^{14}$, and nutrient analysis was performed using the in-house suite of programs. A preliminary scan of the text data files showed that there were many entries of non-specific 'meat', 'vegetables' or 'pudding'. Representative compositions for these were created, using a 33\% sample of the records to obtain frequencies where these foods had been specified. Thus the composite 'meat' was 57\% beef and $43 \%$ mutton. A composite 'vegetable' was made up of $50 \%$ peas, $21 \%$ cabbage, $16 \%$ green beans and $13 \%$ carrots and a composite 'salad' was 29\% lettuce and $71 \%$ tomatoes. Rice pudding, being the most common one, was assumed for unspecified 'pudding'. 'Bread and butter' was frequently mentioned but margarine was rare. However, in view of the rationing of fats, a composite was assumed, taken as butter $(58 \%)$ and margarine $(42 \%)^{8}$. Tea was assumed to be taken with milk and sugar. One hundred and sixty of the children ate school or nursery dinners. From descriptions, a standard meal consisting of meat, potatoes and a vegetable followed by custard with stewed fruit or pudding was used for unspecified meals. One-third of a pint of milk was added since this was distributed free to all school or nursery-attending children $^{15}$.

A few (less than 1\%) of the dietary records showed supplements such as cod liver oil and vitamin drops. These were not coded as it was not known how many other children might have been receiving supplements of which there was no record.

Apart from the relatively few that were reported by weight, portion sizes suitable for 4-year-olds were allocated using the amounts of rationed foods available (see Appendix), and Ministry of Health 1949 recommendations on feeding young children ${ }^{15}$, which descibes types of foods suitable for this age group and the quantities that should be given. Since neither of these two sources separated boys and girls, no distinction could be made in the portion sizes for the two genders in the present analysis.

Although the nutrient content of foods in the 1989 DIDO database ${ }^{16-18}$ was satisfactory for many foods, 
others have significantly changed in composition since 1950. Meat had a higher fat content in 1950 and recipes for meat dishes contained a lower proportion of meat to other ingredients. Bread had a different composition due to the higher extraction rate of flour, and there were fewer nutrient fortifications to breakfast cereals. More appropriate nutritive values from contemporary food tables ${ }^{19,20}$ were therefore used for these and other typical foods of the time.

\section{Comparison with other studies}

Comparison was made between the present results and those published from the NDNS of $1992 / 93^{10}$. The NDNS included 493 children aged 3.5-4.5 years, sampled from July 1992 to June 1993. Weighed food intake was recorded for 4 days, two of which were weekend days ${ }^{10}$. Vitamin intake from food and beverage sources only was used in the present comparison with 1950; any supplements were not included.

\section{Data analysis of the 1950 records}

Data analysis was by SPSS for MS Windows 6.0. Analysis of variance and multiple regression analysis was used to examine nutrient differences between groups, taking significance as $P<0.01$. Logarithmic transformations were performed prior to analysis of variance for the nutrients with skewed distributions, i.e carotene, retinol, vitamin A and vitamin C. Chi-square testing was used to examine dichotomous variables, and stepwise logistic regression analysis when testing such variables for the effects of confounders. Significant differences were taken as $P<0.01$.

\section{Results}

Results are presented for food and nutrient intakes obtained from the 1-day diet records in 1950. These were, however, confined to meal times. Although $33 \%$ of the children reportedly had some other foods given between meals, this did not appear to influence total energy and intake of most nutrients (see below). Consumption of sweets was barely recorded in the food records, although the children probably would have taken up their personal ration, which was $5 \mathrm{oz}(142 \mathrm{~g})$ week $^{-1}$. Recorded energy intake may therefore be lower than the total energy intake.

\section{Food intake}

Table 1 shows mean food intake by food group, and frequency of consumption. Results from the NDNS of $1992 / 93^{10}$ are also shown. Since estimated portion weights were used for the 1950 study, amounts of foods consumed can only be approximate. Frequencies in 1992 were published for individual foods rather than food groups, hence only some of the foods in Table 1 can be compared. Comparisons of the percentage of children consuming the various foods should bear in mind that over a single day's record, as in 1950, fewer foods would be encountered than during a 4-day record. In addition, the much larger number of children in 1950 and the nearly complete response rate (98\%), could have introduced a greater diversity between children compared with the 1992 study (81\% response rate).

In the 1950 records, there were some differences in percentage of children consuming individual foods according to the day of the week. Significantly higher frequencies $(P<0.001$, except where shown below) at weekends (predominantly Sundays since there were few records for Saturdays) were found for bacon, milk, eggs, potatoes, puddings, green vegetables, and lower weekend frequencies for orange juice $(P<0.01)$, breakfast cereals, porridge $(P<0.01)$ and jam, while no differences were seen for bread, spreading fats, tea, soup, fruit and cakes plus biscuits. A highly significant trend $(P<0.001)$ through the week was observed for red meat, which ranged from frequencies of $76 \%$ on Sundays to $39 \%$ on Thursdays, and also for fish which was highest on Fridays at $22 \%$ with only $7 \%$ of the Sunday records containing fish.

In terms of weight and consumption frequency, bread and milk were the main components of the diet of the 1950 4-year-olds, but by 1992 much less bread was consumed. The 1992 children ate new foods such as pasta ( $51 \%$ consuming) and pizza (14\% consuming), while the 1950 children ate rice only as a milk pudding. Liquid milk consumption was lower in 1992 but yoghurts and fromage frais were eaten which were unheard of in England in the 1950s. By 1992, the consumption of spreading fats had decreased substantially (only 29\% consuming butter and 34\% margarine), reflecting the lower bread intake.

Fish intake may have been underrepresented in 1950, since few records (only 3\%) covered Fridays which is the traditional day for fish consumption. As shown above, fish occurred on a higher proportion of the diet records for Fridays compared with other days of the week. A higher frequency of fish consumption was found in 1992 (38\% for coated and white fish), due in part to the popularity of fish fingers, which were not encountered in the 1950 data.

Vegetable consumption has decreased since 1950, and of the total weight reported for the 1992 children, a quarter consisted of baked beans which were rarely reported in 1950. The 1992 children also ate less potatoes but had a higher intake of savoury snacks. Fruit consumption was lower in 1950 compared with 1992; 49\% of the latter children consuming apples and pears for example.

Beverages showed the most dramatic change 
Table $1 \mathrm{Mean}^{\star}$ daily weights of food groups consumed, and frequency of consumption by children aged 4 years in national studies in 1950 and $1992 / 93^{10}$

\begin{tabular}{|c|c|c|c|c|}
\hline \multirow[b]{2}{*}{ Food groups } & \multicolumn{2}{|c|}{$\begin{array}{l}\text { NSHD } 1950 \\
(n=4599)\end{array}$} & \multicolumn{2}{|c|}{$\begin{array}{c}\text { NDNS 1992/93 } \\
\quad(n=493)\end{array}$} \\
\hline & g day $^{-1}$ & $\%$ consuming & g day $^{-1}$ & $\overline{\% \text { consuming }}$ \\
\hline Pasta, rice, etc. & $<1$ & $<1$ & 31 & $\dagger$ \\
\hline Bread & 120 & 97 & 48 & $\dagger$ \\
\hline Breakfast cereals & 27 & 59 & 21 & $\dagger$ \\
\hline Cakes & 30 & 48 & 28 & 61 \\
\hline Biscuits & 4 & 28 & 17 & 88 \\
\hline Puddings & 31 & 28 & 21 & $\dagger$ \\
\hline Milk puddings & 71 & 65 & 9 & 23 \\
\hline Milk & 307 & 98 & 247 & $\dagger$ \\
\hline Cream & 3 & 5 & 4 & 17 \\
\hline Cheese & 2 & 8 & 6 & 57 \\
\hline Yoghurts & 0 & 0 & 23 & 33 \\
\hline Eggs & 32 & 55 & 9 & 47 \\
\hline Spreading fats & 20 & 86 & 7 & $t$ \\
\hline Meat (beef, lamb, bacon, etc.) & 24 & 68 & 21 & $\dagger$ \\
\hline Poultry & $\ll 1$ & $<1$ & 11 & $\dagger$ \\
\hline Offal & 1 & 3 & $<1$ & 4 \\
\hline Meat products and dishes & 22 & 23 & 26 & $\dagger$ \\
\hline Fish and fish products & 7 & 11 & 10 & $\dagger$ \\
\hline Leafy vegetables & 13 & 25 & 6 & $\dagger$ \\
\hline Root vegetables & 3 & 7 & 7 & $\dagger$ \\
\hline Pulses, dry & 3 & 4 & 11 & $\dagger$ \\
\hline Other vegetables & 54 & 60 & 35 & $\dagger$ \\
\hline Potatoes & 75 & 79 & 66 & $t$ \\
\hline Fruit and nuts & 36 & 40 & 51 & $\dagger$ \\
\hline Preserves, spreads & 15 & 46 & 2 & $\dagger$ \\
\hline Confectionery & $<1$ & $<1$ & 25 & $\dagger$ \\
\hline Sugar & 6 & 66 & 3 & 57 \\
\hline Tea & 194 & 55 & 35 & 38 \\
\hline Soft drinks and juices & 13 & 11 & 446 & $\dagger$ \\
\hline Sauces, soups, etc. & 16 & 26 & 33 & $\dagger$ \\
\hline
\end{tabular}

*Over all children.

†Frequency for this food group as a whole was not given.

between 1950 and 1992. In 1950, 55\% of the children were drinking tea with meals, but by 1992 tea consumption had fallen to $38 \%$. In contrast the consumption of soft drinks and fruit juices rose from $11 \%$ of the children in 1950 to $90 \%$ having soft drinks and 36\% having fruit juices in 1992 . Note, however, that between-meal drinks may not have been completely recorded in 1950.

\section{Energy and nutrient intake}

Table 2 shows the mean energy and nutrient intake of the 1950 children compared with the 1992/93 NDNS ${ }^{10}$, and recommended nutrient intakes ${ }^{21,22}$. For the 1950 study, there were no significant differences in energy and nutrient intake by day of the week, but since so few records covered Friday or Saturday, the full weekly pattern could not be determined. There were also no significant differences in energy and nutrient intake between boys and girls, but the use of average portion sizes undistinguished by gender may have resulted in greater similarity than actually existed. There was no significant difference in mean energy intake between those children reportedly being given other food between meals and those receiving none. The position was the same for most of the nutrients studied, but for calcium, carotene, retinol and vitamin C, children given food between meals had a slightly but significantly lower intake $(P<0.001)$ compared with those receiving no other food, even after correcting for social class, region and gender.

Mean EI : BMR in 1950 was 1.63 (SD 0.40), and only $2.8 \%$ of the children had an EI : BMR below 0.9, the cutoff point appropriate for a 1-day record, below which the diet record is implausible for this measurement period $^{23}$.

A notable difference between the 1950 data and that of the 1992 data was in total energy consumed, the latter being some $217 \mathrm{kcal} \mathrm{day}^{-1}$ lower. This difference is increased if the potential energy from sweets is added to the 1950 records; the sweet ration of $5 \mathrm{oz}(142 \mathrm{~g})$ week $^{-1}$, if consumed, would have contributed a further $80 \mathrm{kcal} \mathrm{day}^{-1}$.

The lower percentage energy from fat in 1992 was a consequence of the large decline in fat intake, from $64 \mathrm{~g} \mathrm{day}^{-1}$ in 1950 to $49 \mathrm{~g} \mathrm{day}^{-1}$ in 1992, together with an increase in energy from carbohydrate, particularly as sugar, in 1992. The sugar: starch ratio by weight changed from 0.53 (or 0.71 including the estimate for 
Table 2 Mean (median) daily energy and nutrient intakes* of children aged 4 years in national studies in 1950 and $1992 / 93^{10}$

\begin{tabular}{|c|c|c|c|c|c|c|}
\hline & \multirow{2}{*}{$\begin{array}{c}\text { Recommended } \\
\text { dietary } \\
\text { allowance } †\end{array}$} & \multicolumn{2}{|c|}{$\begin{array}{l}\text { NSHD } 1950 \\
(n=4599)\end{array}$} & \multicolumn{2}{|c|}{$\begin{array}{c}\text { NDNS } 1992 / 93 \\
\quad(n=493)\end{array}$} & \multirow{2}{*}{$\begin{array}{c}\text { Reference } \\
\text { nutrient } \\
\text { intake }\end{array}$} \\
\hline & & Mean (median) & SD & Mean (median) & SD & \\
\hline Energy (kcal) & 1500 & 1445 & 343 & 1228 & 257 & 1490 \\
\hline Energy (MJ) & 6.3 & 6.1 & 1.4 & 5.2 & 1.1 & 6.4 \\
\hline Protein (g) & 56 & 46 & 11 & 38.6 & 10.4 & 20 \\
\hline Fat $(g)$ & & 64 & 20 & 48.7 & 13.6 & \\
\hline Carbohydrate (g) & & 180 & 47 & 170 & 38 & \\
\hline Sugar (g) & & 62 & 24 & 93 & 30 & \\
\hline Starch (g) & & 117 & 33 & 77 & 21 & \\
\hline Unavailable carbohydrate $(\mathrm{g})$ & & 13 & 4 & NA & & \\
\hline Non-starch polysaccharides (g) & & NA & & 6.6 & 2.3 & \\
\hline Calcium (mg) & 1000 & 736 & 230 & 610 & 220 & 450 \\
\hline Iron (mg) & 7.5 & 7.7 & 2.1 & 5.9 & 1.7 & 6.1 \\
\hline Retinol $(\mu \mathrm{g})$ & & $738(530)$ & 1273 & $313(254)$ & 501 & \\
\hline Carotene $(\mu \mathrm{g})$ & & $1049(676)$ & 1130 & $957(660)$ & 937 & \\
\hline Vitamin $\mathrm{A}(\mu \mathrm{g})$ & 900 & $912(681)$ & 1285 & $473(386)$ & 533 & 500 \\
\hline Vitamin C (mg) & 15 & $40(34)$ & 26 & $48(38)$ & 37 & 30 \\
\hline$\%$ energy from protein & & 13 & & 13 & & \\
\hline$\%$ energy from fat & & 40 & & 35 & & \\
\hline$\%$ energy from carbohydrate & & 47 & & 52 & & \\
\hline$\%$ energy from starch & & 31 & & 24 & & \\
\hline \% energy from sugar & & 16 & & 28 & & \\
\hline
\end{tabular}

NA, not applicable.

${ }^{*}$ Excluding supplements.

†From British Medical Association ${ }^{21}$

fFrom Department of Health ${ }^{22}$.

sweets) to 1.2 between 1950 and 1992. As well as a lower starch consumption, the 1992 children were consuming less fibre (as non-starch polysaccharides) than the unavailable carbohydrate in 1950. Results obtained for fibre, as unavailable carbohydrate in 1950 and non-starch polysaccharides in 1992, are not directly comparable due to different analytical methods, and no data are available for non-starch polysaccharide content of the foods in 1950 . However, non-starch polysaccharide intake in 1950, if it could have been estimated, would be expected to be higher than in 1992, due to the greater consumption of bread in 1950 which was made from higher extraction rate flour, $85 \%$, compared to $70 \%$ for the predominantly white bread of 1992.

Calcium, iron and vitamin A (particularly retinol) intakes were higher in 1950 compared with 1992. These are reflections of changing food patterns (see below). In contrast, vitamin C intake of the 1950 children $\left(40 \mathrm{mg} \mathrm{day}^{-1}\right)$ was lower than those of 1992 (48 mg day $^{-1}$ ), despite the predominance of summer records in 1950. Vitamin C intake was significantly lower in December 1950, $26 \mathrm{mg} \mathrm{day}^{-1}$ (SD 15, $n=147$ ), than in June, $40 \mathrm{mg} \mathrm{day}^{-1}(\mathrm{SD} \mathrm{25}, n=3337)(P<0.001)$. Intakes for July, $43 \mathrm{mg} \mathrm{day}^{-1}$ (SD $\left.44, n=791\right)$, and August, $38 \mathrm{mg} \mathrm{day}^{-1}$ (SD 20, $n=176$ ), were similar to June.

\section{Contribution by food groups to energy and nutrient intake}

Table 3 shows the percentage contribution of the various food groups to total energy, protein, fat, starch and sugar. Table 4 similarly shows the contributions to calcium, iron, carotene, vitamin $\mathrm{A}$ and vitamin $\mathrm{C}$ intakes. The results from the 1992/93 survey $^{10}$ are included for comparison.

In terms of contribution to total energy intake, bread and fats were much more important in the 1950 diet than in 1992. Most notable was the higher energy contribution from beverages in 1992. Fat spreads made a higher contribution to fat intake in 1950 than in 1992, where potato and savoury snacks featured more prominently. In the 1950 diet, cereal products were the main source of sugars, but by 1992 the main source was beverages.

Figure 1 shows that the contribution from bread to iron intake was considerably higher in 1950 than in 1992, where fortified breakfast cereals were the largest source. Despite the fact that the children ate more meat in 1992, the contribution from meat to iron intake was lower. This is a reflection of the types of meat eaten and the composition of those meats. In 1950 only $1.6 \%$ of the meat eaten was poultry whereas by 1992 the amount of chicken and turkey consumed was 19\% of the total meat. In 1950, chicken had an iron content of $2.1 \mathrm{mg} / 100 \mathrm{~g}$ and beef and mutton $4.4 \mathrm{mg} / 100 \mathrm{~g}^{19}$, while more recent chicken has an iron content of only $0.7 \mathrm{mg} / 100 \mathrm{~g}$ and beef $2.6 \mathrm{mg} / 100 \mathrm{~g}^{18}$.

Milk was the main source of calcium for both sets of children, but cereals and cereal products, including milk puddings, made a larger percentage contribution to the 1950 diet. 
Table 3 Percentage contribution of food groups to macronutrient intake of children aged 4 years in national studies in 1950 ( $n=4599)$ and in $1992 / 93(n=493)^{10}$

\begin{tabular}{|c|c|c|c|c|c|c|c|c|c|c|}
\hline \multirow[b]{2}{*}{ Food group } & \multicolumn{2}{|c|}{ Energy } & \multicolumn{2}{|c|}{ Protein } & \multicolumn{2}{|c|}{ Fat } & \multicolumn{2}{|c|}{ Starch } & \multicolumn{2}{|c|}{ Sugar } \\
\hline & 1950 & $1992 / 93$ & 1950 & $1992 / 93$ & 1950 & $1992 / 93$ & 1950 & $1992 / 93$ & 1950 & 1992/93 \\
\hline $\begin{array}{l}\text { Cereals and cereal products } \\
\text { of which bread } \\
\text { of which biscuits } \\
\text { of which cakes } \\
\text { of which puddings }\end{array}$ & $\begin{array}{r}45 \\
23 \\
1 \\
8 \\
10\end{array}$ & $\begin{array}{r}32 \\
9 \\
10 \\
N R\end{array}$ & $\begin{array}{r}38 \\
22 \\
1 \\
4 \\
8\end{array}$ & $\begin{array}{c}26 \\
10 \\
3 \\
\text { NR } \\
\text { NR }\end{array}$ & $\begin{array}{r}26 \\
7 \\
1 \\
9 \\
8\end{array}$ & $\begin{array}{c}22 \\
\text { NR } \\
7 \\
4 \\
\text { NR }\end{array}$ & $\begin{array}{r}82 \\
56 \\
2 \\
8 \\
7\end{array}$ & $\begin{array}{c}64 \\
25 \\
8 \\
N R \\
\text { NR }\end{array}$ & $\begin{array}{r}35 \\
0 \\
1 \\
11 \\
21\end{array}$ & $\begin{array}{r}22 \\
1 \\
6 \\
\text { NR } \\
\text { NR }\end{array}$ \\
\hline $\begin{array}{l}\text { Milk and milk products } \\
\text { of which liquid milk }\end{array}$ & $\begin{array}{l}15 \\
14\end{array}$ & $\begin{array}{l}16 \\
12\end{array}$ & $\begin{array}{l}22 \\
21\end{array}$ & $\begin{array}{l}28 \\
20\end{array}$ & $\begin{array}{l}20 \\
19\end{array}$ & $\begin{array}{l}22 \\
16\end{array}$ & $\begin{array}{l}0 \\
0\end{array}$ & $\begin{array}{l}0 \\
0\end{array}$ & $\begin{array}{l}24 \\
24\end{array}$ & $\begin{array}{l}18 \\
13\end{array}$ \\
\hline Eggs and egg dishes & 4 & 2 & 9 & 3 & 6 & 3 & 0 & 0 & 0 & 0 \\
\hline Fat spreads & 10 & 4 & 0 & 0 & 26 & 11 & 0 & 0 & 0 & 0 \\
\hline Meat and meat products & 9 & 11 & 19 & 25 & 15 & 17 & 2 & 6 & 0 & 1 \\
\hline Fish and fish products & 1 & 2 & 3 & 4 & 1 & 2 & 0 & 2 & 0 & 0 \\
\hline $\begin{array}{l}\text { Vegetables } \\
\text { of which potatoes } \\
\text { of which savoury snacks }\end{array}$ & $\begin{array}{l}8 \\
6 \\
0\end{array}$ & $\begin{array}{l}13 \\
N R \\
4\end{array}$ & $\begin{array}{l}7 \\
3 \\
0\end{array}$ & $\begin{array}{l}9 \\
4 \\
1\end{array}$ & $\begin{array}{l}4 \\
3 \\
0\end{array}$ & $\begin{array}{r}15 \\
7 \\
7\end{array}$ & $\begin{array}{r}16 \\
14 \\
0\end{array}$ & $\begin{array}{r}26 \\
16 \\
7\end{array}$ & $\begin{array}{l}3 \\
1 \\
0\end{array}$ & $\begin{array}{l}3 \\
0 \\
0\end{array}$ \\
\hline Fruit and nuts & 1 & 3 & 1 & 1 & 0 & 1 & 0 & 1 & 7 & 8 \\
\hline Sugar, preserves and confectionery & 4 & 9 & $<1$ & 3 & 0 & 7 & 0 & 1 & 27 & 22 \\
\hline Beverages & 1 & 8 & 1 & 1 & 1 & 1 & $<1$ & 0 & 3 & 27 \\
\hline Miscellaneous & 1 & 2 & 1 & 1 & 2 & 2 & 0 & 1 & $<1$ & 2 \\
\hline
\end{tabular}

Vegetables were the main source of carotene in both years. Carrots alone provided only 15\% in 1950 but considerably more (47\%) in $1992^{10}$; the predominance of dietary records in June 1950 covered the period of new carrots which contain less carotene than those maturing later in the year ${ }^{18}$.

The change in the relative importance of the sources of vitamin C is shown in Fig. 2. In 1950, vegetables contributed over half of the vitamin $\mathrm{C}$ and beverages under 10\%, whereas in 1992 more than half of the vitamin $\mathrm{C}$ came from fruit juices and soft drinks. Welfare orange juice, which had a high vitamin $\mathrm{C}$ content, provided $8 \%$ of the mean intake of vitamin $\mathrm{C}$ in 1950 , even though only 481 children (10\%) were reportedly given it. Although other soft drinks may have been underrecorded in 1950 if given outside mealtimes,

Table 4 Percentage contribution of food groups to micronutrient intake of children aged 4 years in national studies in 1950 ( $n=4599)$ and $1992 / 93(n=493)^{10}$

\begin{tabular}{|c|c|c|c|c|c|c|c|c|c|c|}
\hline \multirow[b]{2}{*}{ Food group } & \multicolumn{2}{|c|}{ Calcium } & \multicolumn{2}{|c|}{ Iron } & \multicolumn{2}{|c|}{ Carotene } & \multicolumn{2}{|c|}{$\begin{array}{l}\text { Vitamin A } \\
\text { (retinol } \\
\text { equivalents) }\end{array}$} & \multicolumn{2}{|c|}{ Vitamin C } \\
\hline & 1950 & 1992/93 & 1950 & $1992 / 93$ & 1950 & 1992/93 & 1950 & $1992 / 93$ & 1950 & $1992 / 93$ \\
\hline $\begin{array}{l}\text { Cereals and cereal products } \\
\text { of which bread } \\
\text { of which breakfast cereals } \\
\text { of which biscuits } \\
\text { of which milk puddings }\end{array}$ & $\begin{array}{r}39 \\
17 \\
2 \\
<1 \\
13\end{array}$ & $\begin{array}{c}23 \\
8 \\
3 \\
N R \\
\text { NR }\end{array}$ & $\begin{array}{r}46 \\
29 \\
7 \\
1 \\
1\end{array}$ & $\begin{array}{c}50 \\
12 \\
21 \\
6 \\
N R\end{array}$ & $\begin{array}{r}2 \\
0 \\
<1 \\
0 \\
2\end{array}$ & $\begin{array}{l}5 \\
N R \\
N R \\
N R \\
N R\end{array}$ & $\begin{array}{r}10 \\
0 \\
1 \\
0 \\
5\end{array}$ & $\begin{array}{l}10 \\
\text { NR } \\
\text { NR } \\
\text { NR } \\
\text { NR }\end{array}$ & $\begin{array}{l}3 \\
0 \\
0 \\
0 \\
2\end{array}$ & $\begin{array}{l}3 \\
N R \\
N R \\
N R \\
N R\end{array}$ \\
\hline $\begin{array}{l}\text { Milk and milk products } \\
\text { of which liquid milk }\end{array}$ & $\begin{array}{l}50 \\
48\end{array}$ & $\begin{array}{l}59 \\
46\end{array}$ & $\begin{array}{l}2 \\
2\end{array}$ & $\begin{array}{l}5 \\
4\end{array}$ & $\begin{array}{l}9 \\
9\end{array}$ & $\begin{array}{l}6 \\
5\end{array}$ & $\begin{array}{l}24 \\
22\end{array}$ & $\begin{array}{l}31 \\
23\end{array}$ & $\begin{array}{l}8 \\
8\end{array}$ & $\begin{array}{l}6 \\
5\end{array}$ \\
\hline Eggs and egg dishes & 3 & 1 & 8 & 3 & 0 & 0 & 7 & 4 & 0 & 0 \\
\hline Fat spreads & 0 & 0 & $<1$ & 0 & 7 & 4 & 20 & 12 & 0 & 0 \\
\hline Meat and meat products & 1 & 3 & 22 & 15 & 17 & 6 & 27 & 14 & 1 & 2 \\
\hline Fish and fish products & 1 & 1 & 1 & 2 & 0 & $<1$ & 0 & 2 & 0 & 0 \\
\hline $\begin{array}{l}\text { Vegetables } \\
\text { of which potatoes } \\
\text { of which savoury snacks }\end{array}$ & $\begin{array}{l}3 \\
1 \\
0\end{array}$ & $\begin{array}{c}4 \\
N R \\
N R\end{array}$ & $\begin{array}{r}12 \\
5 \\
0\end{array}$ & $\begin{array}{r}15 \\
6 \\
2\end{array}$ & $\begin{array}{r}59 \\
0 \\
0\end{array}$ & $\begin{array}{r}61 \\
N R \\
N R\end{array}$ & $\begin{array}{r}11 \\
0 \\
0\end{array}$ & $\begin{array}{r}22 \\
1 \\
1\end{array}$ & $\begin{array}{r}59 \\
28 \\
0\end{array}$ & $\begin{array}{r}22 \\
13 \\
1\end{array}$ \\
\hline Fruit and nuts & 2 & 1 & 2 & 3 & 4 & 2 & 1 & 1 & 19 & 15 \\
\hline Sugar, preserves and confectionery & 1 & 4 & 3 & 4 & 0 & 1 & 0 & 1 & 3 & 1 \\
\hline Beverages & 1 & 3 & 3 & 2 & $<1$ & 12 & 0 & 4 & 9 & 52 \\
\hline Miscellaneous & $<1$ & 1 & 1 & 2 & $<1$ & 3 & 0 & 1 & 0 & 0 \\
\hline
\end{tabular}

NR, not reported. 


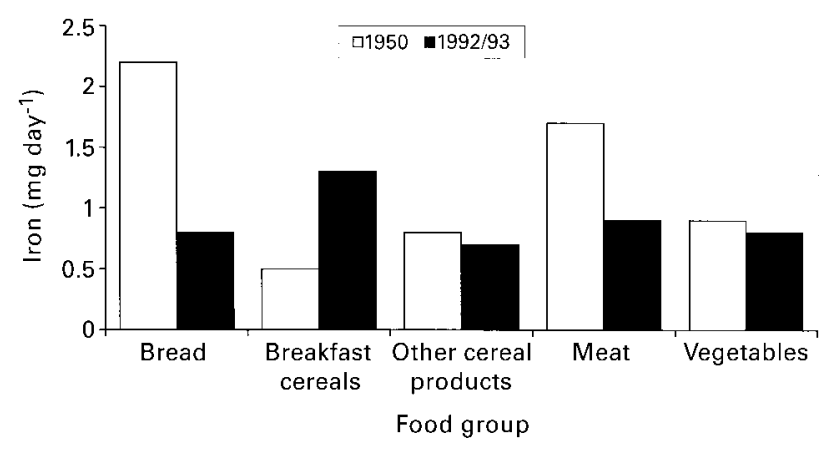

Fig. 1 Comparison of major food sources of iron in the diets of children aged 4 years in national samples in $1950(n=4599)$ and in 1992/93 $(n=493)^{10}$

those that were described at meals were mainly lemonade and carbonated drinks which contain only traces of vitamin $\mathrm{C}^{18}$.

\section{Discussion}

A strong impression emerging from the dietary pattern reported for young children in 1950 was the uniformity of the diet. Most children ate either eggs or cereal with bread and butter for breakfast; meat, potatoes, vegetable and a pudding for lunch; bread, butter and jam, cake and sometimes biscuits for tea; and milk last thing at night. A caveat should be inserted that this diet is not representative of the year as a whole, $90 \%$ of the records were taken in June and July and this is reflected in the seasonal fruit and vegetables that were eaten. Strawberries and rhubarb were the most frequently consumed fruits, and fresh peas, lettuce and tomatoes headed vegetable consumption. Also, there were plenty of eggs available. A rather different picture would have been obtained if more of the records had dated from the winter months.

It appeared that most of these children were eating well considering the social conditions prevalent at the time. In 1950, 24\% of these families were living in overcrowded housing $^{11}$. The war-time rationing system had reduced disparities in food and nutrient intake

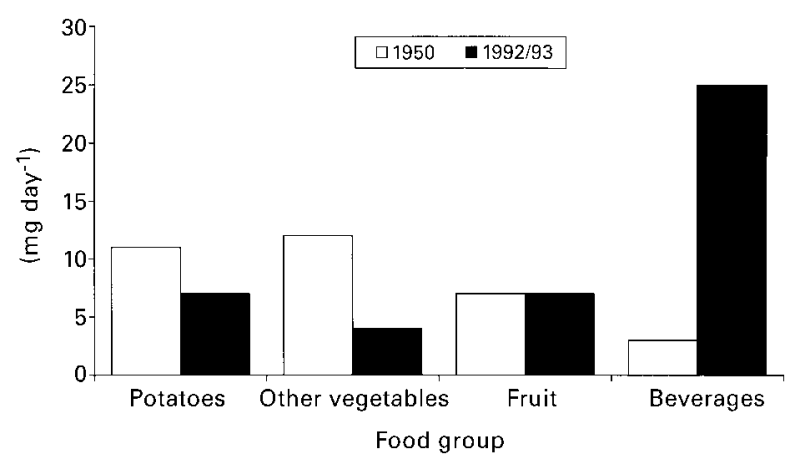

Fig. 2 Comparison of major food and beverage sources of vitamin $C$ in the diets of children aged 4 years in national samples in 1950 ( $n$ $=4599)$ and in 1992/93 $(n=493)^{10}$ between social classes, although not eliminated them ${ }^{21}$. Despite apparent uniformity of dietary pattern, marked social differences were seen in foods eaten by the present study children in $1950^{24}$. This, plus the consequent variations in nutrient intake, could be a contributory factor to the social inequalities of many other aspects of the lives of young children of the early post-war era ${ }^{5}$ which may exert an influence on morbidity and mortality in later life.

Twenty-four-hour recall is a common tool for assessing diet in population studies. Its appeal lies in the simplicity of measurement, enabling large numbers of subjects to be studied at relatively little cost. A high response rate can be achieved as shown by the $98 \%$ for the present study, compared with 61-82\% found for more intensive subject participation using weighed intakes $^{10,25}$. Twenty-four-hour recalls are suitable for assessing group mean intakes of nutrients but they are not appropriate for individual intakes ${ }^{26-29}$. The most efficient way to improve the reliability of the mean for a given number of subject days, $n \times k$ (where $n=$ number of subjects and $k=$ number of days) is to minimize the standard error of the mean (SEM) by making $k=1$ and maximizing $n^{26,28}$. Such conditions were fulfilled in the present study of 1-day measurements from the 4599 children in 1950.

Validation of 24-hour recalls has been attempted by comparison with other dietary methods. The relatively few reported studies give inconsistent results ${ }^{30}$, but only few studies have been conducted with young children $^{27,29,31}$. Close agreement was found between group mean energy and nutrient intakes of 477 4-yearolds assessed by 24-hour recall and by 7-day weighed intakes $^{29}$. Twenty-four-hour recall relies on memory, which can be prone to reporting error, to which are added errors in estimation of portion size. However, circumstances prevailing in 1950 may have mitigated this. The limited availability of foods would have made the mothers more focused on obtaining sufficient for the family and thus aided awareness during the reporting of their child's diet.

Independent validation of energy intake can now be achieved through evaluation in relation to estimated BMR calculated from body weight. Cut-off values, below which the dietary record can be considered implausible, are providing useful validations ${ }^{23,32}$. In the present study, the mean EI:BMR of 1.63 is plausible, and only a small proportion (2.8\%) of the children were below the plausibility cut-off of 0.9 . Recent studies on young children have also found good agreement between energy intake and measured energy expenditure ${ }^{33}$.

Despite differences in methodology, food and nutrient intakes found for the 4-year-olds in 1950 were mostly in good agreement with the national study of 78 children aged $4-5$ years conducted the following 
year ${ }^{25}$, using a 7-day weighed intake. In particular, percentage energy from protein, fat and carbohydrate were virtually identical in the two studies. Recognized differences in reporting of sweets and other snacks by Bransby and Fothergill ${ }^{25}$ would partially account for the higher energy intake they found, comparing the summer of 1950 with the late spring of 1951 would be the main factor behind the lower vitamin C intake in 1951.

In the present study, total energy intake of 4-yearolds was higher in $1950\left(1445 \mathrm{kcal} \mathrm{day}^{-1}\right)$ compared with $1228 \mathrm{kcalday}^{-1}$ found in the NDNS in 1992. Despite not including food eaten between meals, energy intake in 1950 was similar to the then recommended intake ${ }^{21}$. It is likely that children would have been more active in 1950, indicating higher energy needs which is compatible with their higher energy intake. That the lower energy intake of the 1992 children was not due to underreporting is shown by the results of the pilot study to the NDNS, where energy expenditure, measured by the doubly-labelled water technique, and energy intake were extremely close $\mathrm{e}^{34}$.

In 1950, starch intake was considerably higher, and unavailable carbohydrate was double the non-starch polysaccharide intake of 1992. The latter difference is more than can be explained by the difference in analytical methods used to define 'fibre'. By 1992, sugar had replaced starch as the major supplier of carbohydrate energy. These shifts in carbohydrate intake are a striking feature of the present study, and demonstrate that in early life in 1950 , the dietary pattern should have been more beneficial to gastrointestinal health.

Iron intake in 1992 was only $76 \%$ of that in 1950, the decline being exacerbated by the reduced contribution from meat, which has a higher iron bioavailability. Although no blood samples were taken from the 1950 children, a survey of 297 boys aged 6 years in 1952 found an average haemoglobin level of $13.5 \mathrm{~g} / 100 \mathrm{ml}$ $(\mathrm{SD} 1.0)^{35}$. By 1992, lower mean haemoglobin values were found in the survey of 4-year-olds, at $12.4 \mathrm{~g} /$ $100 \mathrm{ml}(\mathrm{SD} 0.9, n=290)^{10}$. However, there is insufficient evidence to determine whether these differences would have had any influence on cognitive development.

The higher calcium intake in 1950 compared with 1992 could have potential benefit for later bone health. Accretion of calcium in childhood and higher peak bone mass in early adulthood are major determinants of osteoporotic risk in later life, although the precise role of calcium intake is complex ${ }^{36}$ and optimal calcium intake in childhood is difficult to determine.

The substantial shift in the sources of vitamin C between 1950 and 1992 is particularly noteworthy. In 1950, almost all vitamin C was derived from plant and vegetable sources, which would also have provided other metabolically active compounds such as flavonoids. These may have important antioxidant roles in protection against cardiovascular disease and, potentially, cancer ${ }^{37}$, although little is known about the time span over which this protective role may be acting. In 1992, vitamin C was obtained predominantly from soft drinks, including fortified ones, thus the provision of other nutrients and substances present in fruits and vegetables would have been more limited.

In conclusion, comparison of food intakes of 4-yearold children across a time span of 40 years has revealed marked differences in total nutrient intake and sources of nutrient supply. In 1950 the diet was still influenced by post-war austerity, but the present study demonstrates that the food and nutrient intake of young children at that time in most respects was arguably better than at present. The greater predominance of bread of higher extraction rate, and of vegetables and a lower sugar intake conforms more closely to modern nutritional guidelines. On the other hand, the percentage energy from fat was higher in 1950, at $40 \%$, and current recommendations are that the diet should contain only $35 \%$ energy as fat by the age of 5 years ${ }^{38}$. In the early post-war period, there was less emphasis on restricting fat intake, and milk drinking by children was encouraged. The importance of fat intake in childhood to later cardiovascular health is the subject of much debate, as are ways of achieving the optimum dietary balance in order to limit fat intake without detrimental effects on full growth potential, or replacement of fat by other potentially adverse energy sources such as sugar ${ }^{39}$. Since the members of the 1946 Birth Cohort are still continuously studied, evaluation of their food intake when they were 4 years old in 1950 will provide much needed data for long-term investigations of early diet and risk of disease in adulthood.

\section{Acknowledgements}

We give grateful thanks to the NSHD staff for transcription of the microfiche archive records, and to Emer Cannon and Ciara Culligan (University of Ulster) for assistance with coding the dietary records.

\section{References}

1 Barker DJP. Fetal nutrition and cardiovascular disaease in later life. Br. Med. Bull. 1997; 53: 96-108.

2 Lucas A. Role of nutritional programming in determining adult morbidity. Arch. Dis. Child. 1994; 71: 288-90.

3 Richards M, Wadsworth MEJ, Rahimi-Foroushani MA, Hardy R, Kuh D, Paul AA. Infant nutrition and cognitive development in the first offspring of a national UK birth cohort. Dev Med. Child Neurol. 1998; 40: 163-7.

4 Winick M. The role of early nutrition in subsequent development and optimal future health. Bull. NY Acad. Med. 1989; 65: 1020-5.

5 Wadsworth MEJ. Changing social factors and their long-term implications for health. Br. Med. Bull. 1997; 53: 198-209.

6 Forsdahl A. Are poor living conditions in childhood and adolescence an important risk factor for arteriosclerotic heart disease? Br. J. Prev. Soc. Med. 1977; 31: 91-5. 
7 Ministry of Food. ABC of Rationing in the United Kingdom. London: Ministry of Food, 1951.

8 Ministry of Food. Domestic Food Consumption and Expenditure 1950. London: HMSO, 1952.

9 Wadsworth MEJ. The Imprint of Time. Oxford: Clarendon Press, 1991.

10 Gregory JR, Collins DL, Davies PSW, Hughes JM, Clarke PC. National Diet and Nutrition Survey: Children aged 1.5 to 4.5 years. Vol 1. Report of the Diet and Nutrition Survey. London: HMSO, 1995.

11 Douglas JWB, Blomfield JM. Children Under Five. London: Allen and Unwin, 1958.

12 Registrar General. Classification of Occupations. London: HMSO, 1961.

$13 \mathrm{WHO} / \mathrm{FAO} / \mathrm{UNU}$. Energy and Protein Requirements. WHO Technical Report Series No. 724. Geneva: World Health Organization, 1985.

14 Price GM, Paul AA, Key FB, et al. Measurement of diet in a large national survey: comparison of computerised and manual coding in household measures. J. Hum. Nutr. Diet. 1995; 8: 417-28.

15 Ministry of Health. The Feeding of Children from One to Five Years. London: HMSO, 1949.

16 Holland B, Unwin ID, Buss DH. Cereals and Cereal Products: Third Supplement to McCance and Widdowson's The Composition of Foods, 4th edn. Nottingham: Royal Society of Chemistry, 1988.

17 Holland B, Unwin ID, Buss DH. Milk and Milk Products: Fourth Supplement to McCance and Widdowson's The Composition of Foods, 4th edn. Cambridge: Royal Society of Chemistry, 1989.

18 Paul AA, Southgate DAT. McCance and Widdowson's The Composition of Foods, 4th edn. London: HMSO, 1978.

19 McCance RA, Widdowson EM. The Chemical Composition of Foods, 2nd edn. MRC Special Report Series No. 235. London: HMSO, 1946.

20 Medical Research Council. Nutritive Values of Wartime Foods. MRC War Memorandum No. 14. London: HMSO, 1945.

21 British Medical Association. Report of the Committee on Nutrition. London: British Medical Association, 1949.

22 Department of Health. Dietary Reference Values for Food Energy and Nutrients for the United Kingdom. Report on Health and Social Subjects No. 41. London: HMSO, 1991.

23 Goldberg GR, Black AE, Jebb SA, et al. Critical evaluation of energy intake data using fundamental principles of energy physiology. 1. Derivation of cut-off limits to identify underrecording. Eur. J. Clin. Nutr. 1991; 45: 569-81.

24 Prynne CJ, Paul AA, Price GM, Wadsworth MEJ. Social class differences in foods eaten by a national sample of four-year old children in 1950. Proc. Nutr. Soc. 1999, in press.

25 Bransby ER, Fothergill JE. The diets of young children. Br.J. Nutr. 1954; 8: 195-204.

26 Beaton GH, Milner J, Corey P, et al. Sources of variance in 24-hour dietary recall data: implications for nutrition study design and interpretation. Am. J. Clin. Nutr. 1979; 32: 25462559 .

27 Bransby ER, Daubney CG, King J. Comparison of results obtained by different methods of individual dietary survey. Br.J. Nutr. 1948; 2: 89-110.

28 Cole TJ, Black AE. Statistical aspects in the design of dietary surveys. In: The Dietary Assessment of Populations. MRC Environmental Epidemiology Unit Report No. 4. Southampton: MRC Environmental Epidemiology Unit, 1984; 5-7.

29 Persson LA, Carlgren G. Measuring children's diets: evaluation of dietary assessment techniques in infancy and childhood. Int. J. Epidemiol. 1984; 13: 506-17.

30 Nelson $\mathrm{M}$. The validation of dietary assessment. In: Margetts BM, Nelson M, eds. Design Concepts in Nutritional Epidemiology, 2nd edn. Oxford: Oxford University Press, 1997; 241-72.
31 Emmons L, Hayes M. Accuracy of 24-hr recalls in young children. J. Am. Diet. Assoc. 1973; 62: 409-15.

32 Black AE, Goldberg GR, Jebb SA, Livingstone MBE, Cole TJ, Prentice AM. Critical evaluation of energy intake data using fundamental principles of energy physiology: 2. Evaluating the results of published surveys. Eur. J. Clin. Nutr. 1991; 45: 583-99.

33 Livingstone MBE, Prentice AM, Coward WA, et al. Validation of estimates of energy intake by weighed dietary record and diet history in children and adolescents. Am. J. Clin. Nutr. 1992; 56: 29-35.

34 Davies PSW, Coward WA, Gregory J, White A, Mills A. Total energy expenditure and energy intake in the pre-school child: a comparison. Br. J. Nutr. 1994; 72: 13-20.

35 Berry WTC, Cowin PJ, Magee HE. Haemoglobin levels in adults and children. BMJ 1952; 1: 411-12.

36 Prentice A. Is nutrition important in osteoporosis? Proc. Nutr. Soc. 1997; 56: 357-67.

37 Hertog M, Kromhout D, Aravanis C, et al. Flavonoid intake and long-term risk of coronary-heart-disease and cancer in the 7 countries study. Arch. Int. Med. 1995; 155: 381-6.

38 Department of Health. Nutritional Aspects of Cardiovascular Disease. Report on Health and Social Subjects No. 46. London: HMSO, 1994.

39 Lifshitz F, Tarim O. Considerations about dietary fat restrictions for children. J. Nutr. 1996; 126 (Suppl.): S1031-41.

\section{Appendix}

Food supplies in Britain were subject to strict controls in the 1940s and early 1950s, which were administered through the Ministry of Food. Much detailed information was published and extracts relevant for the present study are summarized below ${ }^{1-5}$.

\section{General food situation in 1950}

After the extreme shortages and stringent rationing of the immediate post-war years the first half of 1950 showed great improvements in terms of food supply and availability. By June 1950, when the majority of the diet records of the present study were obtained, many of the existing controls had just been finally relaxed, although rationing was still in force for some foods.

\section{The rationing situation in 1950}

The rations varied from month to month depending on the availability of foods. The basic rations for June 1950 are shown in Table $\mathrm{A}^{1}$, and were the same for children and adults, except where specified. At the beginning of 1950 many other foods, except bread, potatoes and preserves, were rationed according to a points system; the foods concerned could be used as desired up to the points allocation during a 4-week period. During the first half of 1950, canned meats, milk, fish, fruit and vegetables, and also dried vegetables, dried fruit and preserves were gradually dropped from the points system until it finally ended on 19 May 1950. 
Table A1 Rations per person in June 1950. Prices are given in predecimalization coinage; $1 \mathrm{oz}=$ $28.4 \mathrm{~g}$

\begin{tabular}{ll}
\hline Bacon and ham & $5 \mathrm{oz}$ per week \\
Cheese & $2 \mathrm{oz}$ per week \\
Butter & $4 \mathrm{oz}$ or 6 oz per alternating week \\
Margarine & $4 \mathrm{oz}$ per week \\
Cooking fats & $2 \mathrm{oz}$ per week \\
Meat & 1 shilling 4 pence carcase meat plus 4 pence corned beef per week \\
Eggs & 125 allocations per year (1 egg per allocation) \\
Tea & $2.5 \mathrm{oz}$ per week (but no ration for children under 5$)$ \\
Sugar & $8 \mathrm{oz}$ per week \\
Chocolate/sweets & $20 \mathrm{oz}$ per 4 weeks
\end{tabular}

${ }^{*}$ Children under 5 years received half rations of meat. The price of fresh meat was around 1 shilling 10 pence per $\mathrm{lb}$, and corned beef 1 shilling 4 pence per $\mathrm{lb}^{2}$, so the actual ration for the under fives was $6 \mathrm{oz}+2 \mathrm{oz}$ per week.

\section{Bread}

To save on imports during the war, the extraction rate of flour had been raised to $85 \%$ (National Wheatmeal), but it was lowered to 80\% on 27 August 1950. In August 1946 , the fortification of flour with calcium carbonate was doubled to $14 \mathrm{oz}$ per $280 \mathrm{lb}$ sack, which is still the current level.

\section{Milk and dairy products}

By January 1950 the sale of milk was unrestricted. Children under 5 years of age could receive 7 pints weekly at 1.5 old pence a pint or free under the Welfare Foods Service. In addition, recognized day nurseries and nursery schools were allowed two-thirds of a pint of milk free for each child attending. The ration of cheese remained very low. In June 1950, cream became available.

\section{Fats}

By 1950 the supply of butter was improving but it had still not reached the pre-war level. Margarine could be taken in place of all or part of the butter ration. The fortification of margarine was standardized so that the vitamin A level was that of butter, while the vitamin D content (from 1942) was double that of butter. These fortification levels are still unchanged. Both in June and August 1950 there were increased allocations of fats to the manufacturers of cake, biscuits and flour confectionery and ice-cream.

\section{Meat}

Pigs and poultry, being cereal consumers in direct competition with man, were particularly affected by wartime restrictions. The meat ration, which was defined by a sum of money, varied from month to month, as did the proportion of canned corned beef. Children under 5 years received half the adult ration. In the first half of $1950,82 \%$ of pig meat went for bacon. On 1 June 1950 price control and distribution of rabbits and hares was discontinued. This was followed by the decontrolling of poultry on 1 July 1950.

\section{Fish}

Fish controls were ended in April 1950. This resulted in a rise in the price of fish.

\section{Eggs}

The production of eggs had been much reduced, consumers were entitled to one egg per allocation but the number of allocations per week depended on the supply available. 1950 was a record year for commercial home production and by March eggs were so plentiful that restrictions on their sale were lifted. By July 1950 domestic supply was diminishing again due to the hens' natural laying cycle and restrictions were back in force by September.

\section{Fruit and vegetables}

In May 1950 controls on the supply of oranges were lifted. Sale of bananas was still restricted to priority consumers: children under 18 years, expectant mothers and those over 70 years. The domestic apple harvest was particularly good in 1950 and they were freed from price control in August 1950. Potatoes were freely available in 1950. Most UK-grown fruit and vegetables had to be distributed fresh as there was a chronic shortage of tin plate for canning.

\section{Welfare Foods Service}

Milk distribution by the Welfare Foods Service has been described above. In addition, children between the ages of 2 and 5 years were eligible for one 6 oz bottle of concentrated orange juice per fortnight for 5 old pence and one bottle of cod liver oil per 6 weeks, free of charge, obtained through Welfare Foods Distribution Centres. The take-up of welfare orange juice nationally was approximately $50 \%$, but proprietary orange juice was also used ${ }^{6}$. Cod liver oil was taken nationally by only around $30 \%$ of those eligible ${ }^{6}$.

\section{School meal service}

From 1944 the provision of a midday meal became obligatory in all grant-aided schools. The original aim was to provide around $1000 \mathrm{kcal}$ and sufficient protein 
and vitamins to make up for a lack in the rest of the diet. In practice, only older children consumed this much ${ }^{7}$. In addition every child received free school milk. A special allowance of dried milk was provided to school canteens at a low price.

\section{References}

1 Ministry of Food. $A B C$ of Rationing in the United Kingdom. London: Ministry of Food, 1951.

2 Ministry of Food. Domestic Food Consumption and Expenditure 1950. London: HMSO, 1952.
3 Ministry of Food. Weekly information. Ministry of Food Bulletin 1950; 528-79.

4 Wright NC. Britain's food supplies. 2. Post-war trends and the task facing British agriculture. Ministry of Food Bulletin 1952; 668: 3-6.

5 Wright NC. Britain's food supplies. 1. The pattern of development up to the end of World War II. Ministry of Food Bulletin 1952; 667: 3-6.

6 Ministry of Health, Department of Health for Scotland. Report of the Joint Subcommittee on Welfare Foods. London: HMSO, 1957.

7 Stewart CP. The composition of school meals. Br. J. Nutr. 1948; 2 : 85-7. 